\title{
Predicting the potential distribution of striped hyena Hyaena hyaena in Iran
} \author{
Abbas Ahmadi ${ }^{3}$, Hamid Reza Rezaei ${ }^{4} \&$ Hamid Toranj-Zar ${ }^{5}$ \\ Gorgan, Iran.

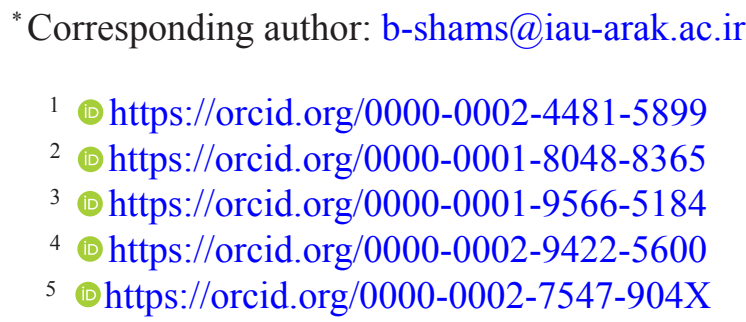

Amirhossein Dadashi-Jourdehi ${ }^{1}$, Bahman Shams-Esfandabad ${ }^{2, *}$,

1,2,3,5 Department of Environmental Science, Arak Branch, Islamic Azad University, Arak, Iran.

${ }^{4}$ Environmental Science Department, Gorgan University of Agriculture and National Resources,

\begin{abstract}
Predictive potential distribution modelling is crucial in outlining habitat usage and establishing conservation management priorities. Association among species occurrence and environmental and spatial characteristics has been calculated with species distribution models. Herein, we used maximum entropy distribution modelling (MaxEnt) for predicting the potential distribution of striped hyena Hyaena hyaena in the entire country of Iran, using a number of occurrence records (i.e., 118) and environmental variables derived from remote sensing. The MaxEnt model showed a high rate of success according to AUC test scores (0.97). Our results are roughly congruent with previous studies suggesting that mountainous regions in northern and western Iran, and the plains in central and eastern Iran are a suitable habitat for H. hyaena.
\end{abstract}

Keywords. Iran, habitat, temperature, occurrence records, MaxEnt modelling, Hyaena hyaena.

Dadashi-Jourdehi A., Shams-Esfandabad B., Ahmadi A., ReZaei H.R. \& Toranj-Zar H. (2020). Predicting the potential distribution of striped hyena Hyaena hyaena in Iran. Belgian Journal of Zoology 150: 185-195. https://doi.org/10.26496/bjz.2020.80

\section{Introduction}

The striped hyaena, Hyaena hyaena (Linnaeus, 1758) is distributed in most parts of Africa (except for the southern parts), the Middle East including the Arabian Peninsula, the Levant, Turkey, Iraq, Iran, and the Caucasus, and extends further into Central Asia and the Indian subcontinent. The species occupies varied types of environments and ecosystems (AKAY et al. 2011; REICHMANN 2005), extending from arid deserts (SINGH et al. 2010; TICHON et al. 2016; WAGNER 2006) to dense Mediterranean shrubland (ABI-SAID \& ABI-SAID 2007; ROSENBERG et al. 2016). It was reported that hyaenas prefer open semi- 
arid habitats (ALAM et al. 2015; WAGNER 2006), and occur in low densities in true deserts and dense vegetation (ABISAID \& DLONIAK 2015). Striped Hyaenas rely on large areas to support their resource requirements (ALAM et al. 2015; WAGNER 2006). The distribution of $H$. hyaena in the Middle East and the Caucasus in particular, is now patchy as the result of a decline which has occurred over the past decades (KASPAREK et al. 2004). Thus, this species has the largest range of distribution among hyaenids (KRUUK 1976). Hyaena hyaena has a wide range of distribution in Iran including mountainous, steppe and desert habitats throughout the country except north and northwestern provinces (ZIAIE 2008; KARAMI et al. 2016).

According to the IUCN criteria, the world status of striped hyenas has been called as "lower risk: near threatened" in the conservation action plan prepared by the IUCN/SSC Hyaena Specialist Group (Mills \& Hofer 1998). In Iran, it is mentioned in "Data Deficient" based on the latter reference and needs to be further investigated in the country.

According to ETEMAD (1985), the Iranian hyaenas belong to the subspecies $H$. h. hyaena (Linnaeus, 1758). The striped hyena occupies an extensive range of habitats and may settle wherever it gets sufficient food supply, adequate cover, and access to water (KRUUK 1976). It generally favors open or thorn bush areas in arid and semi-arid environments (ROSEVEAR, 1974; KRUUK 1976; RIEGER 1978; LEAKEY et al. 1999) to pine forests (AKAY et al. 2011) where water is available within $10 \mathrm{~km}$ (RIEGER 1979).

ZIAIE (2008) believed that the Iranian population of hyenas has severely declined. They live in steppes, semi-deserts, rocky fields and valleys with sparse trees (MILlS \& HOFFER 1998; Fig. 1); they avoid deserts, high altitude areas, dense bushes and forests. Striped hyenas prefer living inside caves (MILLS \& HOFER 1998; YILDIRIM 2010). These animals participate in the ecosystem by eating dead and decaying animal carcasses (Mills \& Hofer 1998; BunAiAn et al. 2001; SingH 2008; STEIN et al. 2013). The dietary preferences of this species include vertebrate (BON et al. 2012) and invertebrate animals, various fruits, vegetables and human-sourced organic wastes (WAGNER 2006). Being a dietary opportunist, hyenas are omnivorous carcass eaters. When starved, they can feed on melons, watermelons, grapes and some other vegetables (MILLS \& HOFFER 1998; YILDIRIM 2010). Recently, factors have generally led to major habitat loss (Fig. 2). Therefore, it is very important to protect the hyenas' habitats. As such, habitat management based on evaluation is strongly recommended as a practical solution.

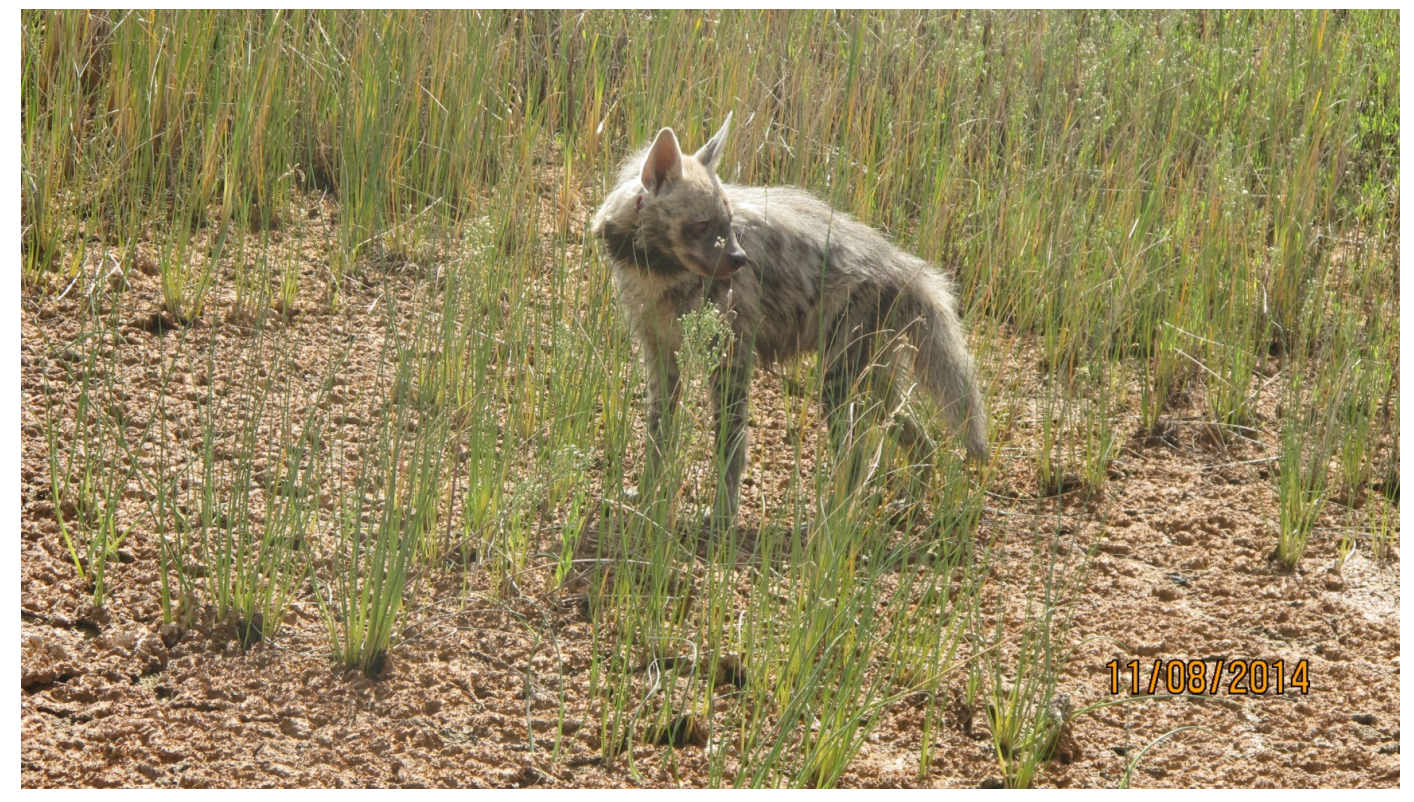

Fig. 1 - Images of Hyaena hyaena in natural habitat (Photo: Reza Aliasl). 
The prediction of distribution patterns of organisms using species distribution models (SDMs) could represent more information about the effects of environmental factors on potential geographical distribution of organisms (ELITH \& LEATHWICK 2009; COLLEVATTI et al. 2013; ESKILDSEN et al. 2013). SDMs are informative tools to map and monitor distribution of organisms, and have become increasingly important in the context of awareness of environmental change and its ecological consequences (MILLER 2010).

Prediction models can forecast changes in distribution and abundance of species. These changes could be the result of future climatic conditions coupled with increases in habitat fragmentation that may result in species extinction (BROWN et al. 1997; WALTHER et al. 2002; ROOT et al. 2003; WAKE 2007). According to the results of predictive models, if climate change continues unchecked, $37 \%$ of global species might be extinct by the end of 2050 (THOMAS et al. 2004). The effects of climate change such as increasing temperatures have been felt from species to community levels (POUNDS et al. 1999; WALTHER et al. 2002; THOMAS et al. 2004). This is a very serious issue for all species, and some regions may bear severe effects.

We used the maximum entropy (MaxEnt) modeling approach which is based on species presence data and environmental factors to predict potential distribution patterns. It is considered one of the most efficient techniques for predicting species distribution models based on presence only data (ELITH et al. 2006; PHILLIPS et al. 2006; EliTH et al. 2011). The aim of this study was to provide a comprehensive distribution map for striped hyena to recognize the environmental variables associated with the predicted distribution of this species using the MaxEnt distribution modeling approach.
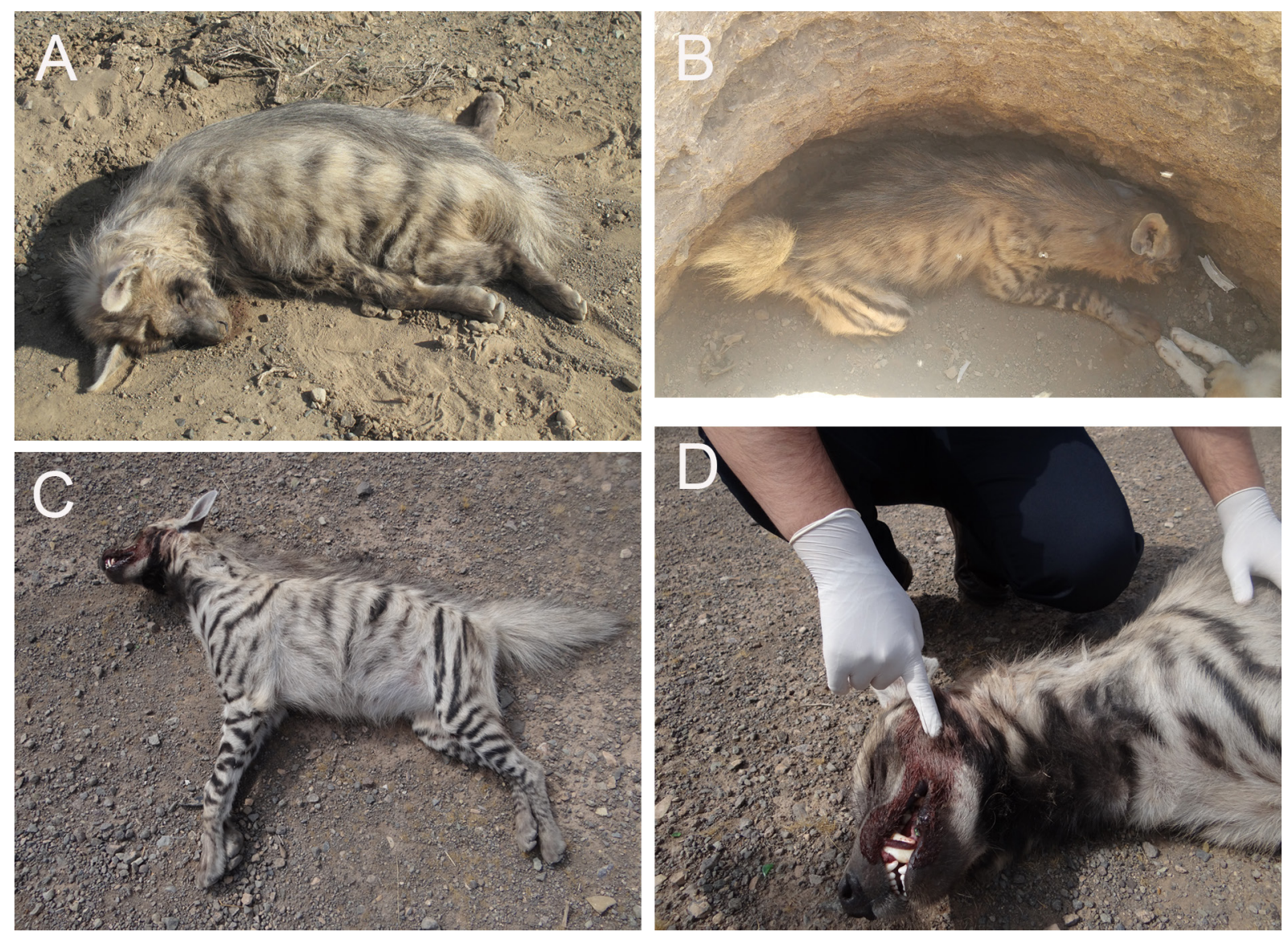

Fig. 2- Images of Hyaena hyaena. A. Killing by farmers. B. Killing for using the genital female system. C-D. Road kill (Photo: Mohammadreza Abedi-Moghadam). 


\section{Material and methods}

A total of 123 locality records for $H$. hyaena was gathered and after removing the duplicated records finally 118 points were used in the maximum entropy distribution modeling approach (Fig. 3). All records of $H$. hyaena were based on our own fieldwork as well as those obtained from the Department of Environment of Iran. Twenty environmental variables including temperature, precipitation, seasonality, and altitude, all with 30-arc-seconds resolution were obtained from the Worldclim data set (http://www.worldclim.org/; HuJMANS et al. 2005) and built in ArcMap version 10. First, correlations between all 21 environmental variables were measured using Pearson's correlation coefficient in SPSS 16. The variables with a correlation coefficient $>0.7$ were excluded from the analysis (RISSLER et al. 2006). Then, 10 out of 21 environmental variables were selected and used in this study (Table 1).

The most common approach for testing the predictive performance is to divide data into 'training' and 'test' datasets. This approach creates relatively independent data for model testing (FIELDING \& BELL 1997; GuISAN et al. 2006). Then, MaxEnt was carried out with default settings when separating records into training and test samples (75 and 25\%, respectively) (PHILLIPS \& DUDíK 2008). Convergence threshold and maximum number of iterations were remained as default ( 0.00001 and 500 , respectively) and auto feature. The cross-validation has been used to evaluate the predictive performance of the model. In addition, Jackknife testing was produced to estimate the average contribution and response of each variable to the model.

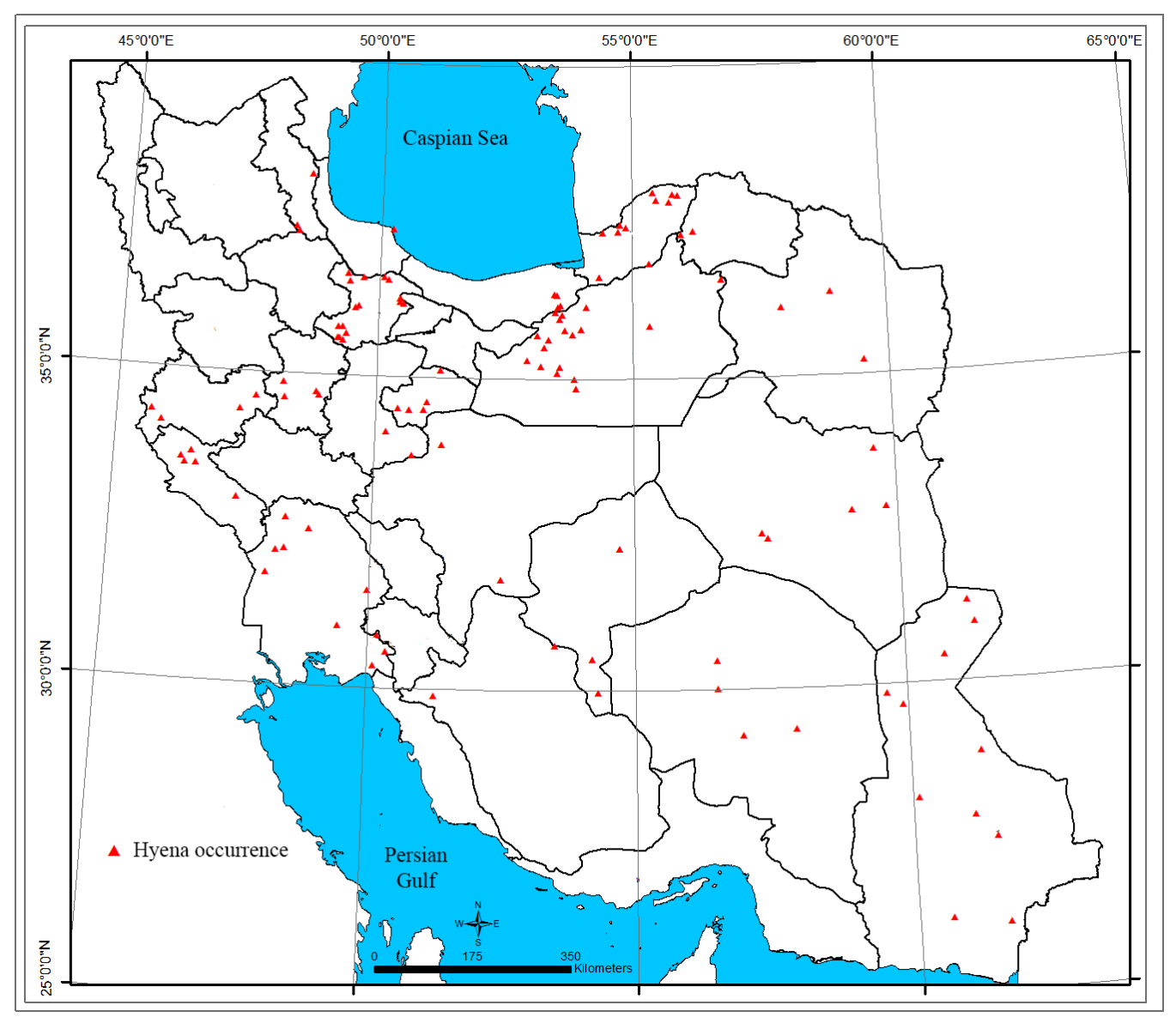

Fig. 3 - Distribution of hyena occurrence points applied in habitat suitability modelling. 
TABLE 1

Percentages of contributions of variables included in the best-fitting distribution model for Hyaena hyaena.

\begin{tabular}{lcc}
\hline Variable & $\begin{array}{c}\text { Percent } \\
\text { contribution }\end{array}$ & $\begin{array}{c}\text { Permutation } \\
\text { importance }\end{array}$ \\
\hline bio8 (Mean Temperature of Wettest Quarter) & 27.4 & 5.9 \\
bio3 (Isothermality) & 16 & 10.9 \\
bio16 (Precipitation of Wettest Quarter) & 14.1 & 44.1 \\
bio4 (Temperature Seasonality (standard deviation *100) & 14 & 10 \\
bio5 (Max Temperature of Warmest Month) & 11.1 & 11.6 \\
Slope & 7 & 11.5 \\
bio6 (Min Temperature of Coldest Month) & 5.1 & 1.1 \\
bio15 (Precipitation Seasonality (Coefficient of Variation) & 2.7 & 2.5 \\
bio17 (Precipitation of Driest Quarter) & 2.1 & 0.9 \\
bio2 (Mean Diurnal Range (mean of monthly max temp - min temp) & 0.3 & 1.4 \\
\hline
\end{tabular}

Our model was tested with 'area' under the receiver-operating characteristic curve (AUC) used extensively in assaying species' distribution models, and measures the ability of a model to differentiate between sites where a species is 'present' versus 'absent' (PHILlips et al. 2006; Elith et al. 2006). Models with $\mathrm{AUC}=0.5$ consider a performance equivalent to random; $\mathrm{AUC}>0.7$ as useful performance, $\mathrm{AUC}>0.8$ as good performance, and finally AUC $\geq 0.9$ as excellent performance (MANEL et al. 2001).

\section{Results}

The most contributing environmental variables are following: bio8 (Mean Temperature of Wettest Quarter, 27.4), bio3 (16\%), bio16 (Precipitation of Wettest Quarter, 14.1\%), bio4 (Temperature Seasonality (standard deviation *100, 14\%) (Table 1). The AUC value of our model was $0.970 \pm 0.03$ and then the performance is excellent (Fig. 4).

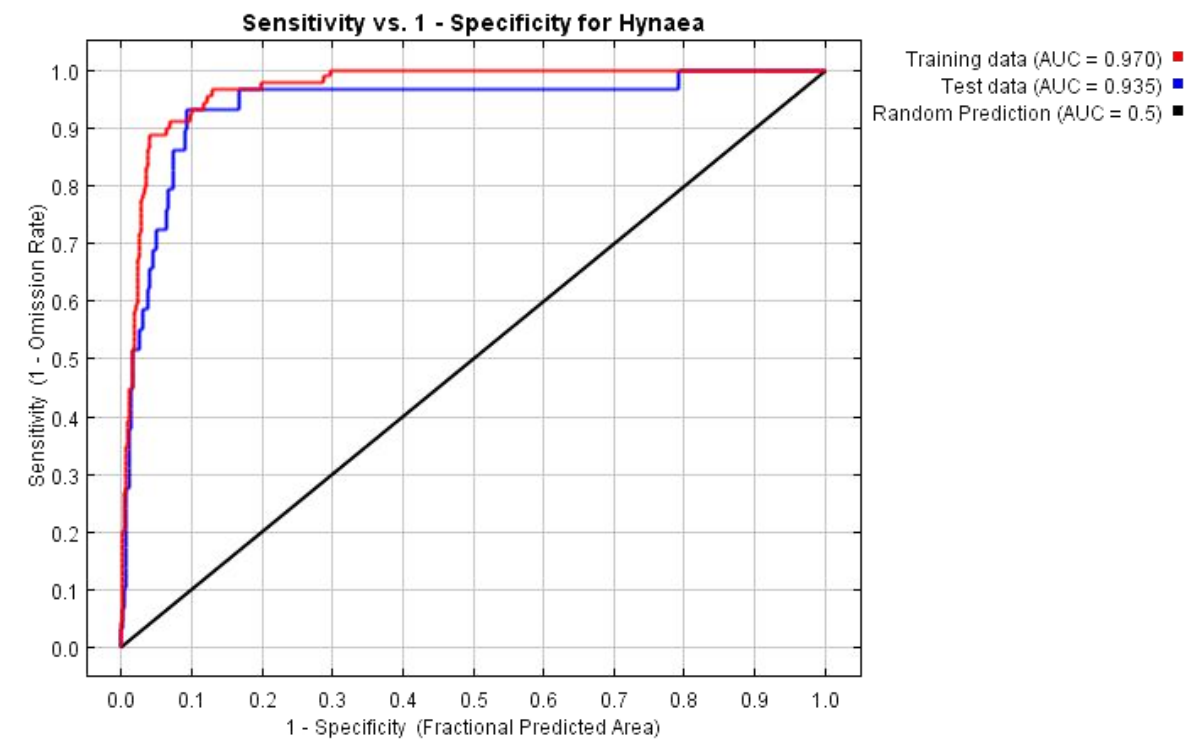

Fig. 4 - Receiver operating characteristic (ROC) curve for the data used in the study. 
Modeling of the potential distribution of $H$. hyaena revealed that the most suitable habitats are mountainous regions in northern and western Iran, and plains regions in central and eastern Iran, as well (Fig. 5).

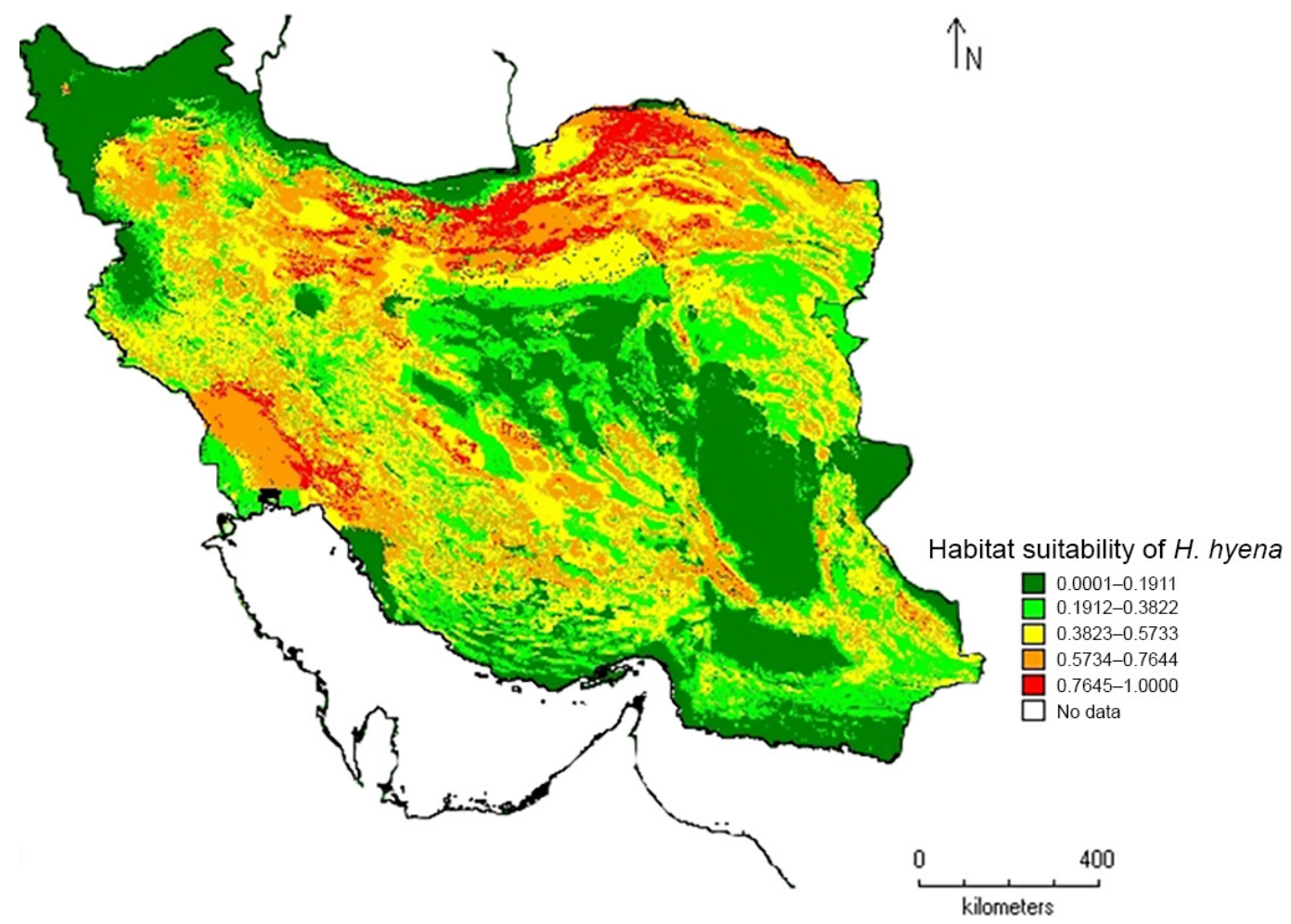

Fig. 5 - Potential distribution of Hyaena hyaena resulting from the best-fitting MaxEnt model. The high suitable habitat is shown in red and regions without any data in white.

\section{Discussion}

According to the results of this study, the central parts of Iran which correspond to Dasht-e-Lut and Dasht-e-Kavir might not be suitable places to find the species. Moreover, north-western and central parts of Iran are not suitable habitat based on modeling. Generally, predicted distribution is approximately congruent with the known distribution pattern. According to SINGH et al. (2014), the striped hyena occurs in habitats with canopy forest and scrub vegetation, where they provide daytime resting sites. In addition, hyenas are mainly distributed in arid and semi-arid regions (RIEGER 1979). Hence, they cannot live in the great deserts of Iran, Dasht-e-Lut and Dasht-e-Kavir, or in cold high-altitude regions of north-western Iran. The species is rarely found across the southern Caucasus, including the neighboring Armenia (KHOROZYAN et al. 2011). Striped hyenas are known to avoid spatially occurring Persian leopard (Panthera pardus saxicolor) habitats in Iran (DAVIS et al. 2018), supporting our modeling results, which did not show a high spatial overlap with suitable landscapes for leopards, particularly north-western Iran (FARHADINIA et al. 2017).

Hyenas play an important role in removing pollution and cleaning the environment (TOURANI et al. 2012), although large parts of the species range are within the current network of protected areas. According to KARAMI et al. (2009), great numbers of hyenas can be observed in western and south-western of Khojir National Park, which is located $20 \mathrm{~km}$ east of Tehran, capital of Iran. The distribution of hyenas depends on climatic conditions, stressful factors, topography, habitat satiation and food availabilities. According 
to ABADE et al. (2014), precipitation is one of the most important environmental factors that affects the distribution of spotted hyenas. The results of our study are congruent with the findings of these authors.

Various factors influencing the distributional pattern of hyenas, such as agricultural activities, livestock, mining, wild dogs, incursion and building of dams such as Mamlo dam located in the territory of the Khojir National Park. As a consequence, the most important cause of mortality of hyena in the country has been reported from Parchin road constructed in the middle of the Park. The model presented by REZAEI et al. (2017) concluded that Hyaena hyaena is successful in finding suitable nesting areas in the Haftad-Gholleh protected area in Iran.

Along with the threat of road strike, illegal hunting is also increasing. Striped hyenas are usually widely distributed among local communities (MOQANAKI et al. 2015; FARHADINIA et al. 2017), but they are rarely engaged in livestock's killing or damaging farm animals (FARHADINIA et al. 2017). Traditionally, the organs of hyenas are used as a medicine and in superstitious beliefs, which have originated from the myth that different parts of the hyena's body are an effective means to ward off evil and to ensure love and fertility (KARAMI et al. 2010; TOURANI et al. 2012; REZAEI et al. 2017). Habitat destruction and land modification stands as an important threat for the species and in some parts, farmers convert natural habitat into agricultural lands and start to kill hyenas to protect their crops. Land conversion reduces food access for hyenas, making predator-prey competition more disturbing. Unfortunately, there is no accurate data on the situation of Hyaena hyaena in neighboring countries, most data come from Iran.

Hence, identifying regions with high a suitability for hyenas can help to manage their conservation activities.

The International Union for the Conservation of Nature (IUCN) considers the striped hyenas to be Near-Threatened (ARUMUGAM et al. 2008). Although a high proportion of the species range is covered within the current network of protected areas in Iran (FARASHI et al. 2017), the species needs specific conservation programs, given that the majority of its suitable habitats lies near human settlements.

This study provides more information about suitable habitat and relevant environmental factors of the striped hyena. Certainly, more information about behavior and population size of the species could be obtained from ongoing research.

\section{Acknowledgments}

We are grateful to Dr Ali Teimori for his kind help and support of the DOE in Tehran and to Mohammad Ali Adibi, Mojdeh Ram, Alireza Mohammadi, Mohammad Reza Abedi Moghaddam, Javad Ghahhari, Maryam Omidi, Hossein Askari, Manijeh Ramon, Mohsen Pakbaz, Mohammad Ebrahim Sehatisabet, Behrooz Jafari, Adel Mola, Meysam Ghasemi and Leila Jolaieifar for their cooperation in collecting data and for providing field survey assistance. The authors especially thank Aida Ajdari and Arash Akbarzadeh for critical reading of previous versions of the manuscript and editing the English. The authors thank Dr Mohammad Sadegh Farhadinia and Dr Andrew Jacobson for helpful comments on a preliminary draft of the manuscript.

\section{References}

Abade L., Macdonald D.W. \& Dickman A.J. (2014). Using landscape and bioclimatic features to predict the distribution of lions, leopards and spotted hyaenas in Tanzania's Ruaha landscape. PLoS One 9: e96261. https://doi.org/10.1371/journal.pone.0096261 
ABI-SAID M. \& DLONIAK S.M.D. (2015). Hyaena hyaena. The IUCN Red List of Threatened Species: e.T10274A45195080. https://doi.org/10.2305/IUCN.UK.2015-2.RLTS.T10274A45195080.en

ABI-SAID M.R. \& ABI-SAID D.M. (2007). Distribution of the Striped Hyaena (Hyaena hyaena syriaca Matius, 1882) (Carnivora: Hyaenidae) in urban and rural areas of Lebanon. Zoology in the Middle East 42: 3-14. https://doi.org/10.1080/09397140.2007.10638241

AKAY A.E., INAC S. \& YILDRIM I.C. (2011). Monitoring the local distribution of striped hyenas (Hyaena hyaena L.) in the Eastern Mediterranean Region of Turkey (Hatay) by using GIS and remote sensing technologies. Environmental Monitoring and Assessment 181: 445-455.

https://doi.org/10.1007/s10661-010-1840-6

ALAM M.S., KhAn J.A. \& PATHAK B.J. (2015). Striped hyena (Hyaena hyaena) status and factors affecting its distribution in the gir national park and sanctuary, India. Folia Zoologica 64: 32-39.

Arumugam R., Wagner A. \& Mills G. (2008). Hyaena hyaena. In: IUCN Red List of Threatened Species. Available from https://www.iucnredlist.org/species/10274/45195080 [accessed 1 October 2020].

Bon C., Berthonaud V., Maksud F., Labadie K., Poulain J., Artiguenave F., Wincker P., Aury J.-M. \& Elalouf J.-M. (2012). Coprolites as a source of information on the genome and diet of the cave hyena. Proceedings off the Royal Society B 279 (1739): 1-6. https://doi.org/10.1098/rspb.2012.0358

Brown J.H., VAlone T.J. \& CuRTin C.G. (1997). Reorganization of an arid ecosystem in response to recent climate change. Proceedings of the National Academy of Sciences 94 (18): 9729-9733. https://doi.org/10.1073/pnas.94.18.9729

Bunaian F., Hatough A., Ababaneh D., Mashaqbeh S., Yousef M. \& Amr Z.S. (2001). The Carnivores of the Northeastern Badia, Jordan. Turkish Journal of Zoology 25: 19-25.

Collevatti R.G., Terribile L.C., De Oliveira G., Lima-Ribeiro M.S., Nabout J.C., Rangel T.F. \& DiNIZ-FILHO J.A.F. (2013). Drawbacks to palaeodistribution modelling: the case of South American seasonally dry forests. Journal of Biogeography 40: 345-358. https://doi.org/10.1111/jbi.12005

Davis C.L., Rich L.N., Farris Z.J., Kelly M.J., Di Bitetti M.S., Di Blanco Y., Albanesi S., Farhadinia M.S., Gholikhani N., Hamel S., Harmsen B.J., Wultsch C., Kane M.D., Martins Q., Murphy A.J., SteEnweg R., Sunarto S., TAKTEHRAni A., Thapa K., TUCKER J.M., Whittington J., Widodo F.A., Yoccoz N.G. \& MilLer D.A.W. (2018). Ecological correlates of the spatial cooccurrence of sympatric mammalian carnivores worldwide. Ecology Letter 21 (9): 1401-1412. https://doi.org/10.1111/ele.13124

Elith J., Phillips S.J., Hastie T., Dudík M., Chee Y.E. \& Yates C.J. (2011). A statistical explanation of MaxEnt for ecologists. Diversity and Distribution 17 (1): 43-57.

https://doi.org/10.1111/j.1472-4642.2010.00725.x

Elith J. \& LEATHWICK J.R. (2009). Species distribution models: ecological explanation and prediction across space and time. Annual Review of Ecology, Evolution, and Systematics 40: 677-697.

https://doi.org/10.1146/ANNUREV.ECOLSYS.110308.120159

Elith J., Graham C.H., ANDERSON R.P., Dudík M., FERRIER S., GuisAn A., HiJMANS R.J., HuETtMANN F., Leathwick J.R., Lehmann A., Li J., Lohmann L.G., Loiselle B.A., Manion G., Moritz C., Nakamura M., Nakazawa Y., McC.M. Overton J., Peterson A.T., Phillips S.J., Richardson K. SCACHETti-Pereira R., Schapire R.E., Soberón J., Williams S., WiSZ M.S. \& ZimMERmann N.E. (2006). Novel methods improve predictions of species distribution from occurrence data. Ecography 29 (2): 129-151. https://doi.org/10.1111/j.2006.0906-7590.04596.x 
Eskildsen A., Le RouX P.C., Heikkinen R.K., Høye T.T., Kissling W.D., PÖYry J., Wisz M.S. \& LuOTO M.. (2013). Testing species distribution models across space and time: high latitude butterflies and recent warming. Global Ecology and Biogeography 22 (12): 1293-1303.

https://doi.org/10.1111/geb.12078

ETEMAD E. (1985). The Mammals of Iran. Volume II. Iranian Department of Environment, Tehran, India.

FARHADINIA M.S., JOHNSON P.J., HunTER L.T. \& MACDONALD D.W. (2017). Wolves can suppress goodwill for leopards: Patterns of human-predator coexistence in northeastern Iran. Biological Conservation 213A: 210-217. https://doi.org/10.1016/j.biocon.2017.07.011

FIELDING A.H. \& BELL J.F. (1997). A review of methods for the assessment of prediction errors in conservation presence/absence models. Environmental Conservation 24: 38-49.

https://doi.org/10.1017/S0376892997000088

Guisan A., Broennimann O., Engler R., Vust M., Yoccoz N.G., Lehmann A. \& Zimmermann N.E. (2006). Using niche-based models to improve the sampling of rare species. Conservation Biology 20 (2): 501-511. https://doi.org/10.1111/j.1523-1739.2006.00354.x

HiJmans R.J., CAmeron S.E., Parra J.L., Jones P.G. \& Jarvis A. (2005). Very high resolution interpolated climate surfaces for global land areas. International Journal of Climatology 25: 1965-1978. https://doi.org/10.1002/joc.1276

KARAMI M., RIAZI B. \& KALANI N. (2009). Seasonal distribution of striped hyaena (Hyaena hyaena hyaena) in Khogir National Park, Iran. Journal of Environmental Science \& Engineering 10 (2)(37): $100-105$.

Karami M., Riazi B., Kalani N., Islami DehKordi M. \& MAhDaVi A. (2010). Investigating the Attitude of Local Individuals toward Persian Stripes (Hyaena hyaena hyaena) In Khojir National Park. Journal of Environmental Science \& Engineering 10: 281-293.

KARAMI M., GHADIRIAN T. \& FAIzOLAHI K. (2016). The Atlas of Mammals of Iran. Iran Department of the Environment, Tehran.

KaspareK M., Kasparek A., GözcelioĞLu B., ÇolaK E. \& YiĞIT N. (2004). On the status and distribution of the striped hyaena, Hyaena hyaena, in Turkey. Zoology in the Middle East 33: 93-108. https://doi.org/10.1080/09397140.2004.10638068

KhOROZYAn I., MALKhasyan A. \& MurTskHVALADZE M. (2011). The striped hyaena Hyaena hyaena (Hyaenidae, Carnivora) rediscovered in Armenia. Journal of Vertebrate Biology 60 (3): 253-262. https://doi.org/10.25225/fozo.v60.i3.a10.2011

KRUUK H. (1976). Feeding and social behavior of the striped hyaena (Hyaena vulgaris Desmarest). African Journal of Ecology 14 (2): 91-111. https://doi.org/10.1111/j.1365-2028.1976.tb00155.x

Leakey L.N., Milledege S.A.H., Leakey S.M., Edung J., Haynes P., KiPtoo D.K. \& McGeorge A. (1999). Diet of striped hyaena in Northern Kenya. African Journal of Ecology 37 (3): 314-326. https://doi.org/10.1046/j.1365-2028.1999.00180.x

MANEL S., William H.C. \& ORMEROD S.J. (2001). Evaluating presence-absence models in ecology: the need to account for prevalence. Journal of Applied Ecology 38 (5): 291-931. https://doi.org/10.1046/j.1365-2664.2001.00647.x

MiLler J. (2010). Species distribution modeling. Geography Compass 4 (6): 490-509. https://doi.org/10.1111/j.1749-8198.2010.00351.x

Mills M.G.L. \& Hofer H. (eds) (1998). Hyaenas. Status Survey and Conservation Action Plan. IUCN/ SSC Hyaena Specialist Group, IUCN, Gland, Switzerland and Cambridge, UK. 
Moqanaki E.M., Jafarzadeh F., Hosseini-Zavarei F. \& Farhadinia M.S. (2015). Assessing the status of the Eurasian lynx (Lynx lynx) in Anguran Wildlife Refuge using multiple survey methods. Journal of Animal Environment 7 (3): 47-56.

Available from http://www.aejournal.ir/article_11936_en.html [accessed 13 October 12020].

PHILLIPS S.J. \& DudíK M. (2008). Modeling of species distributions with Maxent: new extensions and a comprehensive evaluation. Ecography31 (2): 161-175.https://doi.org/10.1111/j.0906-7590.2008.5203.x

Phillips S.J., ANDERSON R.P. \& SChaPIRE R.E. (2006). Maximum entropy modeling of species geographic distributions. Ecological Modelling 190 (3-4): 231-259.

https://doi.org/10.1016/j.ecolmodel.2005.03.026

Pounds J.A., Fogden M.P.L. \& CAMPBell J.H. (1999). Biological response to climate change on a tropical mountain. Nature 398: 611-615. https://doi.org/10.1038/19297

Reichmann A. (2005). Population Size and Behavior of Striped Hyena in northern Israel. Israel's Nature and Parks Authority, Jerusalem (unpubl. report). [In Hebrew.]

Rezaei S., NADERI S. \& KarAmi P. (2017). The ecological study of Striped hyena (Hyaena hyaena) denning regions in Haftadgholeh protected area using Maximum Entropy method. Journal of Natural Environment 70 (2): 351-362. https://doi.org/10.22059/JNE.2017.141708.1091

RIEGER I. (1978). Social behavior of the striped hyena at Zurich Zoo. Carnivore 1 (2): 49-60.

RIEGER I. (1979). A review of biology of striped hyena, Hyaena hyaena (Linné 1758). Säugetierkundliche Mitteilungen 27 (2): 81-95.

Rissler L.J., Hijmans R.J., Graham C.H., Moritz C. \& Wake D.B. (2006). Phylogeographic lineages and species comparisons in conservation analysis: a case study of California herpetofauna. The American Naturalist 167: 655-666.

Root T.L., Price J.T., Hall K.R., Schneider S.H., Rosenzweig C. \& Pounds A. (2003). Fingerprints of global warming on wild animals and plants. Nature 421: 57-60.

Rosenberg B., Reichman A. \& Shamoon H. (2016). Striped Hyena (Hayena hyaena) Movement Patterns near Haifa City, Mt. Carmel, Israel. Israel's Nature and Parks Authority, Jerusalem. [In Hebrew.]

Rosevear D.R. (1974). Carnivores of West Africa. British Museum of Natural History, London.

SingH P. (2008). Population Density and feeding Ecology of the striped Hyaena (Hyaena hyaena) in Relation to Land Use Patterns in an arid Region of Rajasthan. The Manipal University, Karnataka, India.

Singh P., Gopalaswamy A.M. \& Karanth K.U. (2010). Factors influencing densities of striped hyenas (Hyaena hyaena) in arid regions of India. Journal of Mammalogy 91 (5): 1152-1159. https://doi.org/10.1644/09-MAMM-A-159.1

Singh R., QuREShi Q., SANKAR K., Krausman P.R., Goyal S.P. \& NichOlson K.L. (2014). Population density of striped hyenas in relation to habitat in a semi-arid landscape, western India. Acta Theriologica 59: 521-527. https://doi.org/10.1007/s13364-014-0187-8

Stein A.B., Fuller T.K. \& MARKer L.L. (2013). Brown Hyaena Feeding Ecology on Namibian Farmlands. African Journal of Wildlife Research 43: 27-32.

Thomas C.D., Cameron A., Green R.E., Bakkenes M., Beaumont L.J., Collingham Y.C., Erasmus B.F.N., De Siqueira M.F., Grainger A., Hannah L., Hughes L., Huntley B., Van JaArsveld A.S., Midgley G.F., Ortega-Huerta M.A., Peterson A.T., Phillips O.L. \& Williams S.E. (2004). Extinction risk from climate change. Nature 427: 145-148. https://doi.org/10.1038/nature02121 
TICHON J., ROTEM G. \& WARD P. (2016). Estimating abundance of striped hyenas (Hyaena hyaena) in the Negev Desert of Israel using camera traps and closed capture-recapture models. European Journal of Wildlife Research 63 (5): 1-13. https://doi.org/10.1007/s10344-016-1069-y

TOURAni M., MoQAnaki E.M. \& Kiabi B.H. (2012). Vulnerability of striped hyaenas, Hyaena hyaena, in a human-dominated landscape of Central Iran. Zoology in the Middle East 56: 133-136. https://doi.org/10.1080/09397140.2012.10648948

Wagner A.P. (2006). Behavioral Ecology of the Striped Hyaena (Hyaena hyaena). Montana State University, Boeman, Montana.

WAKE D.B. (2007). Climate change implicated in amphibian and lizard declines. Proceedings of the National Academy of Sciences 104: 8201-8202. https://doi.org/10.1073/pnas.0702506104

Walther G.R., Post E., Convey P., Menzel A., Parmesan C., Beebee T.J.C., Fromentin J.-M., Hoegh-GuldBerg O. \& BAIRLEIN F. (2002). Ecological responses to recent climate change. Nature 416: 389-395.

YILDIRIM İ.C. (2010). Hatay yöresinde çizgili sırtlan (Hyaena hyaena L.). Ekolojisi üzerine araştırmalar. Kahramanmaraş Sütçü İmam Üniversitesi, Fen Bilimleri Enst. Orman Müh. ABD, Kahramanmaraş, Türkiye.

ZIAIE H. (2008). A Field Guide to Mammals of Iran. $2^{\text {nd }}$ Edition. Wildlife Center Publication, Iran.

Manuscript received: 9 December 2019

Manuscript accepted: 28 September 2020

Published on: 14 October 2020

Branch editor: Johan Michaux 